\title{
Historical population dynamics and demography of the eastern Atlantic pomacentrid Chromis limbata (Valenciennes, 1833)
}

\author{
Vera S. Domingues ${ }^{\mathrm{a}, \mathrm{b}, *}$, Ricardo S. Santos ${ }^{\mathrm{b}}$, Alberto Brito ${ }^{\mathrm{c}}$, Vitor C. Almada ${ }^{\mathrm{a}}$ \\ ${ }^{a}$ Instituto Superior de Psicologia Aplicada, Unidade de Investigação em Eco-Etologia, R. Jardim do Tabaco 34, 1149-041 Lisboa, Portugal \\ ${ }^{\mathrm{b}}$ Departamento de Oceanografia e Pescas, Universidade dos Açores, 9901-862 Horta, Azores, Portugal

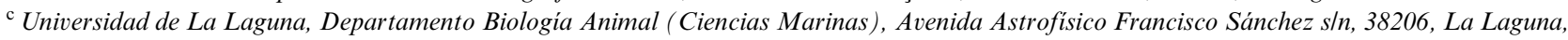 \\ Tenerife, Islas Canarias, Spain \\ Received 24 October 2005; accepted 8 February 2006 \\ Available online 5 April 2006
}

\begin{abstract}
Recent studies have focused on the relationship between the marine fauna of the eastern Atlantic and the Mediterranean Sea, but within the Atlantic, little is known about genetic relationships between populations of the Macaronesian islands. In this study, we tested whether the paleo-climatology and paleo-oceanography of the region could predict the genetic relationships among three eastern Atlantic populations (Azores, Madeira, and Canaries) of a damselfish, Chromis limbata, and compared our results with its Mediterranean and adjacent Atlantic sister species, Chromis chromis. We combined phylogeographic and coalescent approaches using the fast evolving mitochondrial control region gene. No population structure was found for the three archipelagos. The coalescence time estimated for $C$. limbata (0.857-1.17 Mya) was much greater than that estimated for $C$. chromis. We propose that this difference reflects differences in glaciating extents in the Northeastern Atlantic and the Mediterranean. Diversity indexes (Hd and genetic distances) together with historical demographic parameters of $C$. limbata $(\Theta$ and $g$ ) revealed a more stable population history when compared to $C$. chromis. Our results suggest that the Macaronesian populations of $C$. limbata have probably been less affected by the last glaciation than the Mediterranean populations of $C$. chromis. Migration across the three archipelagos was estimated and a prevailing northwest trend was detected. This result supports the idea of a colonization of the Azores by warm water fish from Madeira or the westernmost Canary islands which acted as major glacial refugia for the tropical and subtropical marine fauna during the glaciations.
\end{abstract}

(C) 2006 Elsevier Inc. All rights reserved.

Keywords: Chromis limbata; Northeastern Atlantic islands; Phylogeography; Glaciations; D-loop

\section{Introduction}

To understand the relationships between speciation and dispersal/population dynamics in marine species, genetic connectivity between populations are usually studied across geographic boundaries. Recently, studies have focused on the relationship between the eastern Atlantic and Mediterranean (Alvarado Bremer et al., 2005; Bargelloni et al., 2003, 2005; Costagliola et al., 2004; Domingues et al., 2005; Lemaire et al., 2005; Naciri et al., 1999; Stamatis et al.,

\footnotetext{
${ }^{*}$ Corresponding author. Fax: +351 218860954.

E-mail address: veradomingues@ispa.pt (V.S. Domingues).
}

2004; Zardoya et al., 2004). In contrast, little is known about genetic relationships between populations of the Macaronesian islands (Azores, Madeira, Canaries, and Cape Verde; Almada et al., 2005; Guillemaud et al., 2000). These isolated oceanic islands constitute interesting model systems for the study of colonization processes, as several climatic and oceanographic phenomena have played a major role in the history of the ichthyofauna of these islands (Almada et al., 2001; Miller, 1984; Santos et al., 1995; Zander, 1980).

During the Pliocene, the eastern Atlantic experienced a progressive cooling that reached its extreme with the Pleistocene glaciations (Adams et al., 1999; Briggs, 1996). The western coast of Portugal was particularly affected by a 
very pronounced southward migration of the polar front, which caused a significant dropping of sea water temperatures in this region (Crowley, 1981; Dias et al., 1997). The Madeira islands, located further south, were less affected, while the Canaries were severely affected due to its proximity to the continent, although probably less in the western islands, which nowadays present the higher temperatures (Barton et al., 1998) and warmer fauna of all the temperate Macaronesia (Brito et al., 2001). The Cape Verde islands, although remaining considerably warm, were clearly out of the Tropical bio-region (Briggs, 1996). The sea surface temperatures in the Azores region experienced a small cooling $\left(2-3{ }^{\circ} \mathrm{C}\right)$ (Crowley, 1981). Several authors (Briggs, 1974; Miller, 1984; Santos et al., 1995) suggested that this drop in sea surface temperatures has probably resulted in mass extinctions of littoral fish at the Azores, and that most of the organisms now present would have recolonized the islands after this glaciating event from some southern regions such as Madeira.

In marine organisms, oceanographic conditions play an important role in colonization processes, particularly in those whose dispersal is restricted to their planktonic larval phase. The Northeastern Atlantic current system is dominated by the Gulf Stream, which splits into two main branches, the North Atlantic Current (flowing north) and the Azores Current (flowing east). Close to the Azores islands, each of these currents divides into two branches, one of which flows south, feeding the Madeira and Canaries currents (Santos et al., 1995; Stramma, 1984). This multibranch system is even more complex due to seasonal variations of the mean current directions, and as it is a source of meanders and eddies (Santos et al., 1995; Stramma, 1984). Although dominant average ocean current circulation reaches the Northeastern Atlantic islands from the west, the marine littoral fauna and flora of the temperate Macaronesia (Azores, Madeira, and Canaries) share affinities with the eastern coasts of the Atlantic and the Mediterranean (Boury-Esnault and Lopes, 1985; Brito et al., 2001; Brito and Ocaña, 2004; Gofas, 1990; Lloris et al., 1991; Prud'homme van Reine, 1988; Weerdt, 1989; Wirtz and Martins, 1993). This is probably the result of episodic anomalies of the water movements described above (Santos et al., 1995), and of the temperate conditions that the northwest African upwelling confers to these islands.

Chromis limbata (Valenciennes, 1833) is a species restricted to the Macaronesian islands (Azores, Madeira, and Canaries) and the western coast of Africa (between Senegal and Congo, Edwards, 1986; Wood, 1977; L. Rocha et al., unpublished). The Cape Verde islands bear an endemic and a tropical amphiatlantic Chromis species (Edwards, 1986). Chromis chromis (Linnaeus, 1758), the most likely sister species of C. limbata (Edwards, 1986; Wood, 1977; L. Rocha et al., unpublished) is found in the Mediterranean and adjacent Atlantic. Chromis limbata inhabits rocky areas from 3 to $50 \mathrm{~m}$, where it forms aggregations in midwater (Brito et al., 2002). During the summer, nesting males defend territories and take care of the eggs that are attached to the substratum (Mapstone and Wood, 1975). In the case of C. chromis, after a pelagic larval phase of 18-19 days (Raventós and Macpherson, 2001) fish settle to adult grounds. It is likely that $C$. limbata have similar life history parameters.

The goal of this study was to test whether the paleo-climatology and paleo-oceanography of the region could predict the genetic relationships among the three eastern Atlantic populations (Azores, Madeira, and Canaries) of Chromis limbata. Our working hypothesis was that relict populations of $C$. limbata from the Madeira refugium would have been the source of re-colonization of the other two populations. To address this question, we combined a phylogeographic and coalescent approach using the fast evolving mitochondrial control region gene.

\section{Materials and methods}

\subsection{Sampling and DNA extraction}

Samples of C. limbata were obtained from one island of the archipelagos of the Azores, Madeira, and the Canaries (Fig. 1). C. chromis (C. limbata sister species) was used as outgroup. Samples were collected by spear fishing or hand nets while scuba diving. Fin clips were cut immediately after collection of the individuals and stored at ambient temperature in $95 \%$ ethanol. Tissues were digested overnight at $55^{\circ} \mathrm{C}$ in $700 \mu \mathrm{l}$ of extraction buffer $(400 \mathrm{mM} \mathrm{NaCl}$, $10 \mathrm{mM}$ Tris, $2 \mathrm{mM}$ EDTA, $1 \%$ SDS). We purified the DNA by standard chloroform extraction and isopropanol precipitation (Sambrook et al., 1989).

\subsection{DNA amplification and sequencing}

Amplification of the $5^{\prime}$ hypervariable portion of the mitochondrial control region (also called D-loop) was accomplished with universal primers CR-A and CR-E (Lee et al., 1995), and used a cycling profile of $45 \mathrm{~s}$ at $94^{\circ} \mathrm{C}, 45 \mathrm{~s}$ at $52^{\circ} \mathrm{C}, 1 \mathrm{~min}$ at $72^{\circ} \mathrm{C}$, for 35 cycles. Each $13 \mu 1$ reaction contained 5-50 ng of DNA, $10 \mathrm{mM}$ Tris-HCL (pH 8.3), $50 \mathrm{mM} \mathrm{KCl}, 1.5 \mathrm{mM} \mathrm{MgCl}, 1.25 \mathrm{u}$ of Taq DNA polymerase (Perkin-Elmer, Norwalk, Conn.), $150 \mathrm{mM}$ of each $\mathrm{dNTP}$, and $0.3 \mathrm{mM}$ of each primer. After purification following the manufacturer's protocol (Applied Biosystems, Forter City, CA), direct sequencing was performed with an ABI 3100 automated sequencer (Applied Biosystems).

\subsection{Data analysis}

We used the computer program Clustal V implemented by Sequence Navigator (Applied Biosystems) to align the sequences. Number of haplotypes and haplotype diversity were calculated using the software package DNAsp (Rozas et al., 2003).

Phylogenetic relationships of $C$. limbata individuals were assessed using the neighbor-joining and maximum parsimony methods implemented by the software package PAUP 


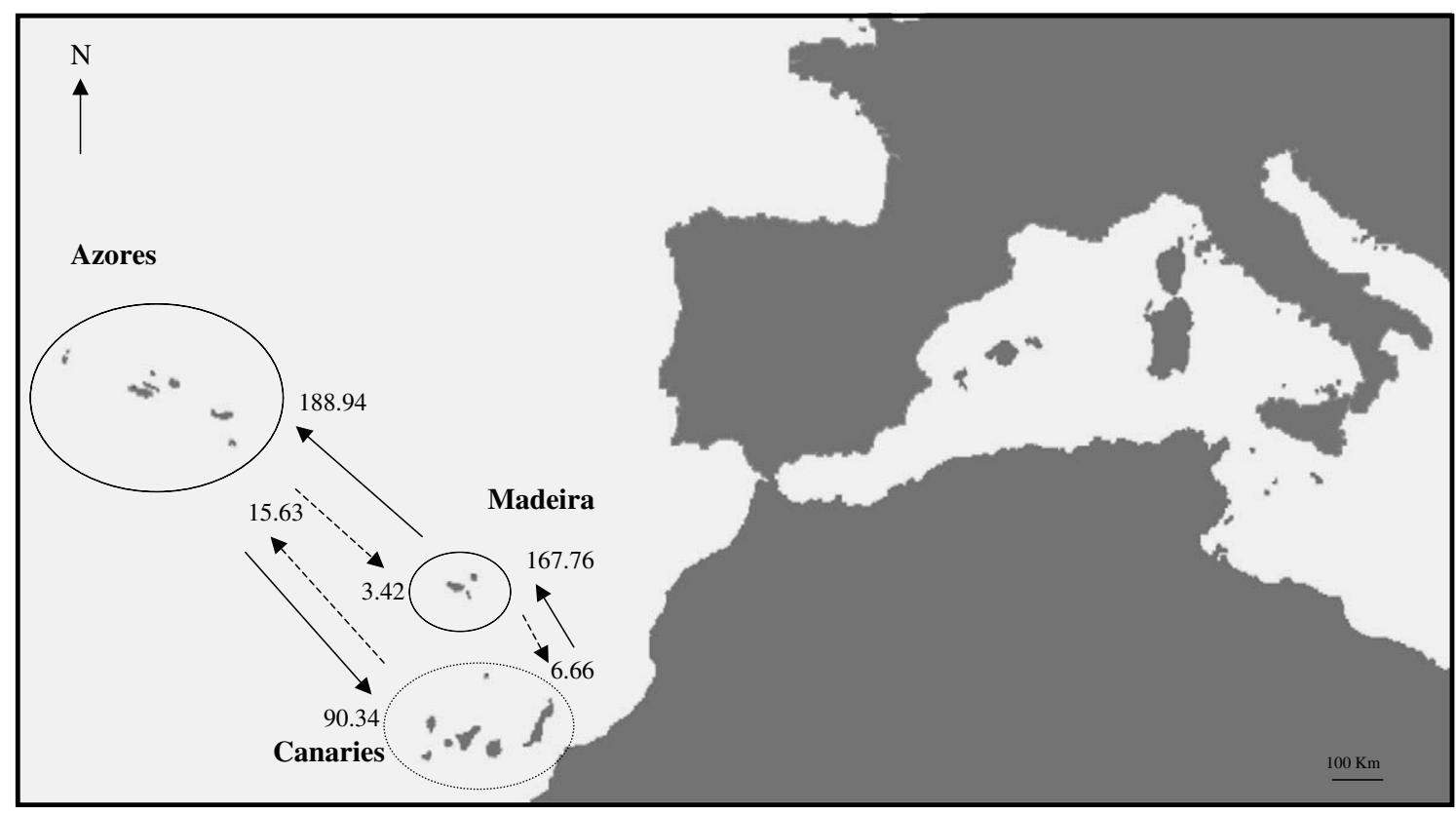

Fig. 1. Chromis limbata sampling locations. C. limbata samples were collected in one island of the archipelagos of the Azores, Madeira, and the Canaries. Arrows indicate the direction of migration between the islands and numbers next to the arrows are the number of immigrants per generation, estimated using Migrate version 2.0 (Beerli, 2004).

(Version 4.0; Swofford, 1998). Since, we were assessing an intraspecific phylogeny, we adopted a model of evolution with as few assumptions as possible and selected Kimura-2-distance (Kimura, 1980). Topological confidence was evaluated for both methods with 1000 bootstrap replicates (Felsenstein, 1985). Additionally, a network of haplotypes was constructed using the statistical parsimony method (Templeton et al., 1992) implemented in TCS (Version 1.21, Clement et al., 2000).

Gene flow (Fst and $\mathrm{Nm}$ ) was estimated using ARLEQUIN (Version 2.000; Schneider et al., 2000). Population structure was estimated by an analysis of molecular variance (AMOVA; Excoffier et al., 1997) using ARLEQUIN 2.0.

The historical demography of the islands was first examined using mismatch distributions analysis and Tajima's test of neutrality (Tajima, 1989), to evaluate possible events of population expansion and decline. These analyses were performed in ARLEQUIN 2.0. Theoretical studies have shown that populations in long stable demographic equilibrium show a chaotic mismatch distribution, while recent rapid population expansions or bottlenecks are reflected in a unimodal (approximately Poisson) profile (Rogers, 1995; Rogers and Harpending, 1992). Mismatch distributions were established and their fit to Poisson distributions was assessed by Monte Carlo simulations of 1000 random samples. The sum of squared deviations (SSD) between observed and expected mismatch distributions was used as a test statistics, its $p$ value representing the probability of obtaining a simulated SSD larger or equal to the observed one (Schneider and Excoffier, 1999). Tajima's $D$ test are classically used to test neutrality, but they can also be used to test population growth as a population that has been experiencing expansion may result in a rejection of the null hypothesis of neutrality (significant negative $D$ value).
Estimates of $\Theta(=2 \mathrm{~N} \mu$, where $\mu$ is the mutation rate for mitochondrial control region), were made for the entire $C$. limbata sample using FLUCTUATE (Kuhner et al., 1998). The parameter $\Theta$ was estimated under an assumption of unconstrained exponential growth. Seeds for all analyses were generated randomly. Analyses were repeated 10 times per region to ensure stability of parameters estimates. Final analyses of each dataset employed 10 short Monte Carlo chains of 200 steps each and 5 long chains of length 20,000, with a sample increment of 20 .

The time of coalescence of the islands was estimated by assuming that coalescence was reached when the population size was reduced to $1 \%$ of its present day value, following Wares and Cunningham (2001). In order to estimate coalescence time, we used the mutation rate $(\mu)$ for mitochondrial control region as $8.24 \times 10^{-8}-9.30 \times 10^{-8}$ (Domingues et al., 2005).

Exchanges and range expansions (immigration) between each island were estimated using MIGRATE 2.0 (Beerli and Felsenstein, 2001; Beerli, 2004). Again, analyses were repeated 10 times, to ensure stability of parameter estimates. Final analyses of each dataset employed 10 short Monte Carlo chains with 5000 recorded genealogies and 5 long chains with 50,000 recorded genealogies, and a sample increment of 20 . We applied an exhaustive search using 4 heated chains $\{1,4$, $7,10\}$ and an interval between swapping trees of 1 .

\section{Results}

\subsection{Population diversity and phylogenetic analysis}

A total of 62 mitochondrial control region sequences were obtained for Chromis limbata. Three C. chromis 
sequences were used as outgroup. Number of haplotypes, diversity indexes and uncorrected p-distances are shown in Table 1. The two most southern islands (Madeira and Canaries) showed higher diversity indexes and p-distances than the Azores.

Both methods of phylogenetic inference gave similar topologies (Fig. 2). Individuals from the three islands did not partition into distinct clades, indicating some level of gene flow between islands. Phylogenetic relationships, however, partitioned the samples in two major clades, one containing 10 individuals (6 from Madeira and 4 from the Canaries) and the other containing the remaining samples. The smaller clade was only weakly supported (boostrap replicates, 59 and 51\% for Maximum-Likelihood and Maximum Parsimony, respectively). In the other clade, C. limbata sequences grouped in small and low supported clades, which include individuals from the three islands. Evolutionary relationships among haplotype sequences were also represented in the form of statistical parsimony networks (Fig. 3). C. limbata revealed a complex pattern with three networks and 13 haplotypes that could not be connected under the confidence limit of $95 \%$ (Templeton et al., 1992). The two larger networks included individuals from the three islands, which supports a lack of geographical structure. The entire network is also characterized by several closed loops instead of linear relationships connecting haplotypes, suggesting the presence of homoplasy (Templeton et al., 1992). Two haplotypes present exclusively in the Azores were inferred to be ancestral, as they yielded the highest outgroup weights in each of the networks $(0.467$ and 0.162) (Castelloe and Templeton, 1994).

\subsection{Population structure}

Population structure was first assessed by looking at gene flow between the Azores, Madeira, and Canary islands (Table 2). Consistent with the phylogenetic description above, gene flow was high between the three archipelagos. Number of migrants was higher between Madeira and the Canary islands than between either of these islands and the Azores. The Azores population showed similar Fst values for the two southern island groups. The analysis of molecular variance showed no population structure for the Azores, Madeira, and the Canaries. There were a high percentage of within popula- tion variation for the three archipelagos $(89.5 \%)$, and a low percentage of variation between populations $(10.5 \%)$.

\subsection{Historical demography}

To investigate the presence of a past demographic expansion or bottleneck, mismatch distribution analyses were performed. Given the lack of population differentiation for C. limbata, the three islands were analyzed in a combined sample. Methods showed contrasting results, making the occurrence of past changes in population size unclear. According to the goodness of fit test, $C$. limbata could be fitted to an expansion model $(\mathrm{SSD}=0.0046$, $p=0.356$ ). This method is however very conservative, rarely rejecting the expansion model (Schneider and Excoffier, 1999). Indeed, visual inspection of the mismatch distributions (Fig. 4) showed a multimodal profile, which is typical of demographic stable populations (Rogers and Harpending, 1992). This outcome was supported by a non-significant Tajima's $D$ value $(D=-0.999, p=0.158)$.

Theta $(\Theta)$ and growth $(g)$ values were estimated for $C$. limbata (Table 3). When compared to populations of C. chromis (Domingues et al., 2005), C. limbata was growing at a slow rate (Table 3 ).

Migration between the Azores, Madeira, and Canary islands was determined. The prevailing migration direction was towards the northwest (Fig. 1). Number of migrants was higher from the Canaries into Madeira and from Madeira into the Azores. Migration in the other directions could not be excluded, although it occurs in a much smaller extend (6.66 from Madeira into the Canaries and 3.42 from the Azores into Madeira; see Fig. 1).

\section{Discussion}

In a previous paper, Domingues et al. (2005) estimated the timing of speciation of $C$. chromis based on the mitochondrial control region, using two approaches: (i) determining the time of divergence between $C$. chromis and its sister species $C$. limbata (using a molecular clock based on the divergence between the transisthmian geminate species $C$. multilineata and C. atrilobata); ii) estimating the age of the most recent common ancestor using the time of coalescence for the two sister species. The divergence time of $C$. chromis

Table 1

Collection localities of Chromis limbata and outgroup species, C. chromis, used in the present study and diversity indexes for mitochondrial control region

\begin{tabular}{|c|c|c|c|c|c|c|}
\hline Locality & Number individuals & $\mathrm{Hn}$ & $\mathrm{Hd}$ & $\pi$ & p-distance (average) & $\overline{\text { Collection date }}$ \\
\hline \multicolumn{7}{|l|}{ Chromis limbata } \\
\hline Azores (Azo) & 25 & 12 & 0.48 & 0.036 & 0.033 & Feb. 2004 \\
\hline Madeira (Mad) & 18 & 17 & 0.94 & 0.058 & 0.057 & Sep. 2003 \\
\hline
\end{tabular}

Chromis chromis

Sesimbra (Ses) (Portuguese Atlantic coast)

3

Mar. 1997

Number of individuals, number of haplotypes (Hn), Haplotype diversity (Hd), Nucleotide diversity ( $\pi$ ), and average uncorrected p-distance for each population are shown. 




Fig. 2. Phylogenetic relationship within Chromis limbata using C. chromis as outgroup. A neighbor-joining tree is shown with neighbor-joining (above the nodes) and maximum parsimony (below the nodes) bootstrap support above $50 \%$. Labels are described in Table 1 . The length of each branch is proportional to the number of nucleotide substitutions. Scale bar: $1 \%$ Kimura-2 genetic distance.

from its sister species C. limbata was estimated at 0.933.26 Mya, while its time of coalescence was reached 0.14 0.21 Mya (Table 3). In the case of C. limbata, coalescence time was estimated at $0.857-1.17$ Mya. These results are in agreement with the general idea that the divergence time of two sister species is most likely an overestimate of their 

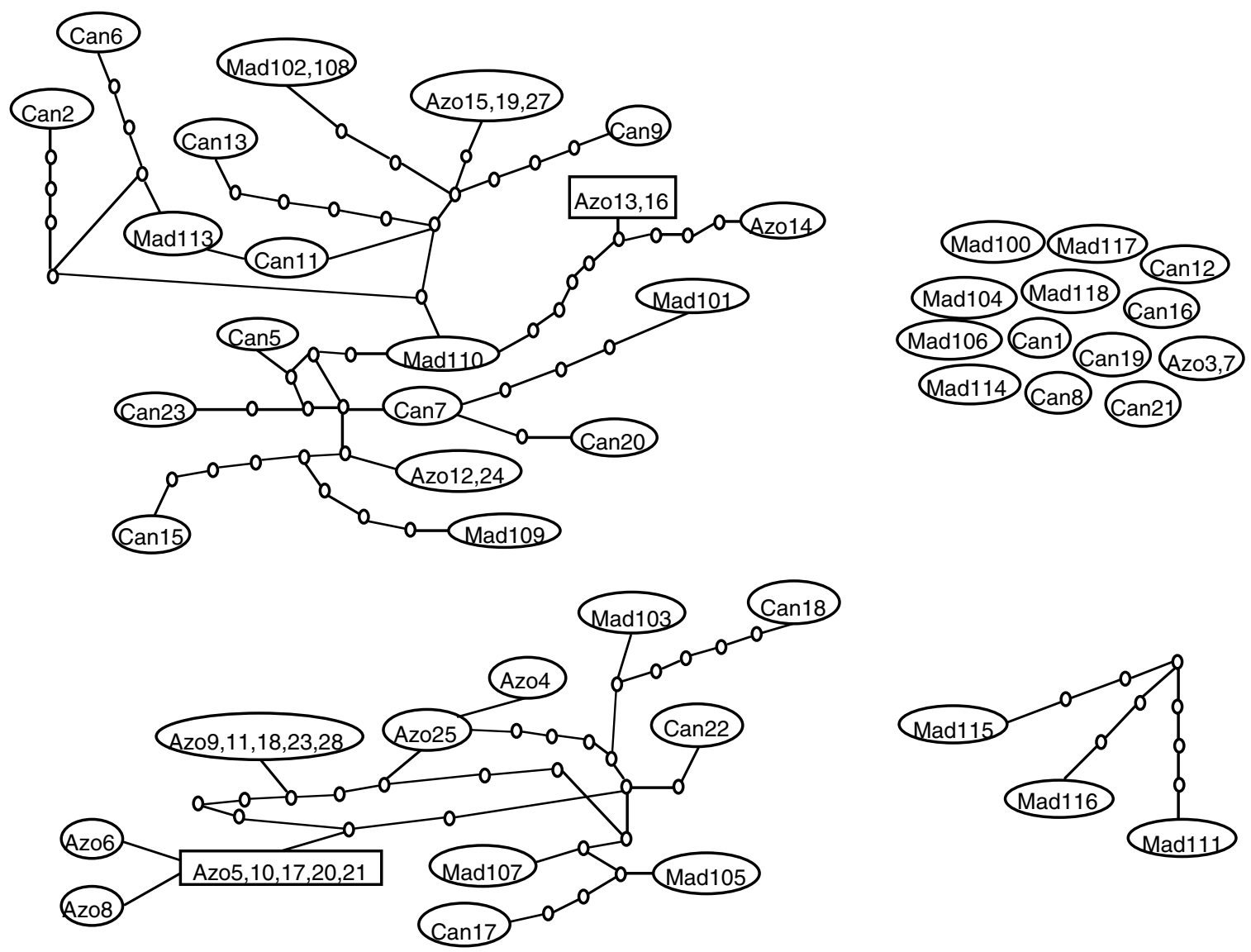

Fig. 3. Statistical parsimony networks of D-loop sequences for C. limbata samples. Empty circles represent missing haplotypes. Ancestral haplotypes for each network (Castelloe and Templeton, 1994) are displayed in a square.

Table 2

Gene flow among Chromis limbata populations represented by Fst (below the diagonal) and $\mathrm{Nm}$ (above the diagonal), calculated from mitochondrial control region sequences using ARLEQUIN version 2.000 (Schneider et al., 2000)

\begin{tabular}{lllc}
\hline & Azores & Madeira & Canaries \\
\hline Azores & & $2.623^{*}$ & $4.189^{*}$ \\
Madeira & $0.160^{*}$ & & 13.744 \\
Canaries & $0.107^{*}$ & 0.035 & \\
\hline
\end{tabular}

Significant $p$ values $(p<0.05)$ are indicated by an asterisk.

actual coalescence time (Edwards and Beerli, 2000). As stated above, the coalescence time estimated for $C$. limbata is much greater than that estimated for $C$. chromis by Domingues et al. (2005). This difference may reflect the differentiate impact of glaciations in the two areas. While in the Atlantic islands, specially in Madeira, the drop in sea surface temperature was negligible (Crowley, 1981), in the Mediterranean warm water fish were reduced to small pockets in the southern Mediterranean (Thiede, 1978), which must have implied a major population collapse of $C$. chromis.

No population structure was found among $C$. limbata from the Azores, Madeira, and Canary islands. None of the phylogenetic inference methods yielded highly supported clades encompassing individuals from one of the islands exclusively. Similarly, the statistical parsimony network showed no particular groupings of individuals across islands. The lack of population differentiation was supported by a low percentage of variation between populations $(10.5 \%)$ shown by the AMOVA analyses. Indeed, gene flow among the three islands was high (Table 2), with all the comparisons showing $\mathrm{Nm}$ values greater than 1 .

Historical demographic parameters of $C$. limbata (Table 3) reveal a more stable population history when compared to C. chromis of the Western Mediterranean and adjacent Atlantic (Domingues et al., 2005). In addition to the differences of coalescence times discussed above, two lines of evidence support this conclusion. Western Mediterranean C. chromis showed a smaller $\Theta$ (and thus smaller $\mathrm{Ne}$ ) than $C$. limbata. Although the difference is not very large $(\Theta=0.541$ and 0.572 for the Western Mediterranean C. chromis and C. limbata, respectively), it is important to remember that the Western Mediterranean and adjacent Atlantic have a much higher area. As for the growth parameter, C. chromis showed much higher values than C. limbata. Large $g$ values are typical of populations expanding their geographical range following regressions due to glaciating events. These observations, which suggest a relatively stable population of $C$. limbata with moderate growth during the Pleistocene, would explain the apparent contradiction between the results of the mismatch analysis and the nonsignificant Tajima's $D$ value. 


$$
\begin{aligned}
& \mathrm{SSD}=0.0046(\mathrm{p}=0.356) \\
& \tau=12.82 \\
& \theta_{0}=5.42 \\
& \theta_{1}=68.22 \\
& \text { Tajima's } \mathrm{D}=-0.999(\mathrm{p}=0.158)
\end{aligned}
$$

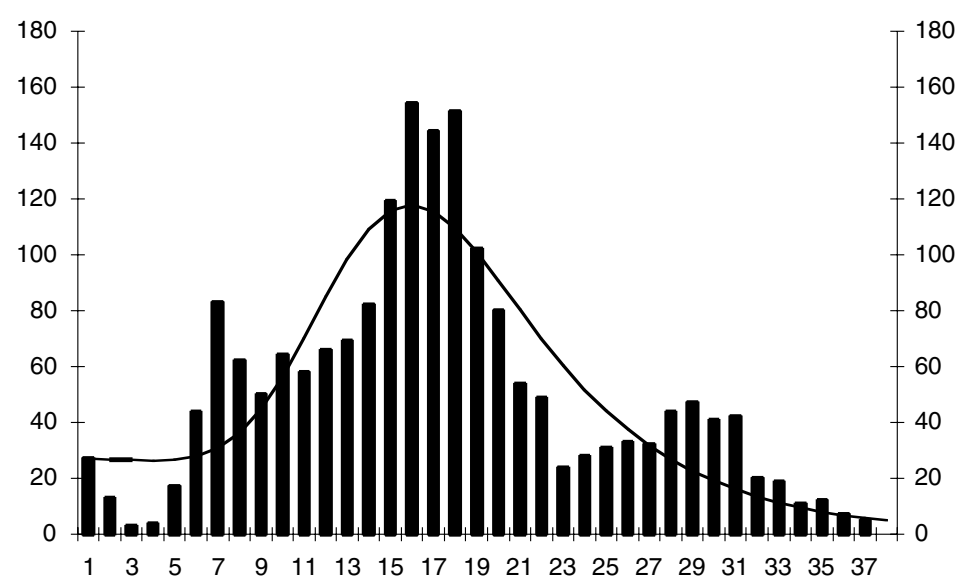

Fig. 4. Mismatch distribution established for Chromis limbata mitochondrial control region. The bars represent the observed frequency of the pairwise differences among haplotypes, while the line shows the expected curve predicted for a population that has undergone a demographic expansion in the past. The parameters of the model of sudden expansion (Rogers and Harpending, 1992) are presented as well as goodness of fit test to the model: SSD sum of squared deviations; $\theta_{0}$ pre-expansion and $\theta_{1}$ post-expansion population sizes; $\tau$ time in number of generations, elapsed since the sudden expansion episode. Tajima's (1989) $D$ test value and its statistical significance are also given.

Table 3

Demographic parameters of Chromis limbata based on mtDNA control region

\begin{tabular}{lclc}
\hline & $\Theta$ & $g$ & $\begin{array}{l}\text { Coalescence } \\
\text { time (Mya) }\end{array}$ \\
\hline $\begin{array}{l}\text { C. limbata } \\
\text { Azo, Mad, Can }\end{array}$ & $0.572( \pm 0.037)$ & $52.678( \pm 5.072)$ & $0.857-1.17$ \\
$\begin{array}{l}\text { C. chromis } \\
\text { Mediterranean }\end{array}$ & $0.897( \pm 0.178)$ & $308.026( \pm 45.979)$ & $0.14-0.21$ \\
\hline
\end{tabular}

Estimates of $\Theta$ (compound parameter representing the effective population size and mutation rate), $g$ (growth parameter), and coalescence time. Parameters were estimated using FLUCTUATE (Kuhner et al., 1998). The standard deviation is presented between parentheses after $\Theta$ and $g$.

In the Azores region during the glacial peaks the drops in sea surface temperatures were small $\left(2-3^{\circ} \mathrm{C}\right)$, due to a complex and stabilizing system of interactions between the Gulf Stream and North Atlantic Current (Crowley, 1981). However, as noted by the same author, the planktonic foraminiferal record in this region has experienced large variations during the last 150,000 years. Indeed, Santos et al. (1995) suggested that this temperature drop, although not very strong, has probably resulted is mass extinctions of littoral fish from the Azores. Following this idea, most of the organisms now present would have recolonized the islands after the last glaciating event from some southern, less affected regions like the Northwestern coast of Africa south of Cape Blanco, the westernmost Canary islands and Madeira. Indeed, both the haplotypic and nucleotidic diversity indexes as well as the uncorrected p-distances were lower for the more affected population of Azores than for the southern
Madeira and Canary islands. When looking at migration across the three archipelagos, a prevailing northwest trend is evident. This estimation agrees with the colonization process proposed by Santos et al. (1995) for the Azores. According to these authors, the western Africa and Macaronesian islands have been the main source of eggs and larvae transported by several eddies and having small islets and shallow seamounts as "stepping-stones" for the dispersal of warm water organisms to the Azores. Also the proximity of the Canary islands to the continental African coast combined with the above mentioned eddies may have played an important role in the colonization process of Madeira and Azores.

In summary, our study shows that the Macaronesian populations of $C$. limbata have probably been less affected by the last glaciation than the Mediterranean populations of $C$. chromis studied by Domingues et al. (2005). It also supports the colonization model proposed by Santos et al. (1995) for the warm water fish of the Azores and the possible role of Madeira and the westernmost Canary islands as a major glacial refugia for the tropical and subtropical marine fauna.

\section{Acknowledgments}

We thank Estação Marítima do Funchal for field work support. This research was partly funded by a Ph.D. Grant SFRH/BD/13069/2003, from the Portuguese Foundation for Science and Technology (VSD). ISPA and IMAR-DOP/UAz are funded by FCT through a pluri-annual and programmatic funding schemes (FEDER). 


\section{References}

Adams, J., Maslin, M., Thomas, E., 1999. Sudden climate transitions during the Quaternary. Prog. Phys. Geogr. 23 (1), 1-36.

Almada, F., Almada, V.C., Domingues, V.S., Brito, A., Santos, R.S., 2005. Molecular validation of the specific status of Parablennius sanguinolentus and Parablennius parvicornis (Pisces: Blenniidae). Sci. Mar. 69 (4), 519-523.

Almada, V.C., Oliveira, R.F., Gonçalves, E.J., Almeida, A.J., Santos, R.S., Wirtz, P., 2001. Patterns of diversity of the north-eastern Atlantic blennid fish fauna (Pisces:Blenniidae). Global Ecol. and Biogeography 10, 411-422.

Alvarado Bremer, J.R., Vinas, J., Mejuto, J., Ely, B., Pla, C., 2005. Comparative phylogeography of Atlantic bluefin tuna and swordfish: the combined effects of vicariance, secondary contact, introgression, and population expansion on the regional phylogenies of two highly migratory pelagic fishes. Mol. Phylogenet. Evol. 36, 169-187.

Bargelloni, L., Alarcon, J.A., Alvarez, M.C., Penzo, E., Magoulas, A., Palma, J., Patarnello, T., 2005. The Atlantic/Mediterranean transition. Discordant genetic patterns in two seabream species, Diplodus puntazzo (Cetti) and Diplodus sargus (L.). Mol. Phylogenet. Evol. 36, 523-535.

Bargelloni, L., Alarcorn, J.A., Alvarez, M.C., Penzo, E., Magoulas, A., Reis, C., Patarnello, T., 2003. Discord in the family Sparidae (Teleostei): divergent phylogeographical patterns across the Atlantic-Mediterranean divide. J. Evol. Biol. 16, 1149-1158.

Barton, E.D., Arístegui, J., Tett, P., Cantón, M., García-Braun, J., Hernández-León, S., Nykjaer, L., Almeida, C., Almunia, J., Ballesteros, S., Basterretxea, G., Escánez, J., García-Weill, L., Hernández-Guerra, A., López-Laatzen, F., Molina, R., Montero, M.F., Navarro-Pérez, E., Rodríguez, J.M., Lenning, K. van., Vélez, H., Wild, K., 1998. The transition zone of the Canary Current upwelling region. Prog. Oceanography 41, 455-504.

Beerli, P., 2004. Migrate: documentation and program, part of Lamark. Version 2.0. <http://evolution.gs.washington.edu/lamarc.html/>.

Beerli, P., Felsenstein, J., 2001. Maximum likelihood estimation of a migration matrix and effective population sizes in $\mathrm{n}$ subpopulations by using a coalescent approach. Proc. Natl. Acad. Sci. USA 98, 4563-4568.

Boury-Esnault, N., Lopes, M.T., 1985. Les démosponges littorales de l'archipel des Açores. Annales de l'institut océanographique. 61 (2), 149-225.

Briggs, J.C., 1974. Marine zoogeography. McGraw-Hill, New York.

Briggs, J.C., 1996. Global Biogeography. Developments in Paleontology and Stratigraphy. vol. 14, Elsevier, Amsterdam.

Brito, A., Falcón, J.M., Aguilar, N., Pascual, P.J., 2001. Vertebrados marinos de Canarias. In: Naturaleza de las Islas Canarias. Ecologi'a y conservación. Editorial Turquesa, Santa Cruz de Tenerife.

Brito, A., Ocaña, O., 2004. Corales de las Islas Canarias. Antozoos con esqueleto de los fondos litorales y profundos. Francisco Lemus Editor, La Laguna.

Brito, A., Pascual, P.J., Falcón, J.M., Sancho, A., González, G., 2002. Peces de las Islas Canarias. Catálogo comentado e ilustrado. Francisco Lemus Editor, La Laguna.

Castelloe, J.T., Templeton, A.R., 1994. Root probabilities for intraspecific gene trees under neutral coalescent theory. Mol. Phylogenet. Evol. 3, 102-113.

Clement, M., Posada, D., Crandall, K.A., 2000. TCS: a computer program to estimate gene genealogies. Mol. Ecol. 9, 1657-1660.

Costagliola, D., Robertson, D.R., Guidetti, P., Stefanni, S., Wirtz, P., Heiser, J.B., Bernardi, G., 2004. Evolution of coral reef fish Thalassoma pavo spp. (Labridae). 2. Evolution of the eastern Atlantic species. Mar. Biol. 144, 377-383.

Crowley, T.J., 1981. Temperature and circulation changes in the eastern north Atlantic during the last 150,000 years: evidence from the llanktonic Fforaminiferal record. Mar. Micropaleontology 6, 97-129.

Dias, J.A., Rodrigues, A., Magalhães, F., 1997. Evolução da linha de costa em Portugal, desde o último máximo glaciário até à actualidade: si'ntese dos conhecimentos. Estudos do Quaternário. 1, 53-66.
Domingues, V.S., Bucciarelli, G., Almada, V.C., Bernardi, G., 2005. Historical colonization and demography of the Mediterranean damselfish, Chromis chromis. Mol. Ecol. 14, 4051-4063.

Edwards, A., 1986. A new damselfish, Chromis lubbocki (Teleostei: Pomacentridae) from the Cape Verde Archipelago, with notes on other Eastern Atlantic pomacentrids. Zoologische Mededelingen. 60 (12), 181-207.

Edwards, S.V., Beerli, P., 2000. Gene divergence, population divergence, and the variance in coalescence time in phylogeographic studies. Evolution 54, 1839-1854.

Excoffier, L., Smouse, P.E., Quattro, J.M., 1997. Analysis of molecular variance inferred from metric distances among DNA haplotypes: application to human mitochondrial DNA restriction data. Genetics 131, 479-491.

Felsenstein, J., 1985. Confidence limits on phylogenies: an approach using the bootstrap. Evolution 39, 783-791.

Gofas, S., 1990. The littoral Rissoidae and Anabathridae of São Miguel, Azores. Açoreana(Suppl.), 97-134.

Guillemaud, T., Cancela, M.L., Afonso, P., Morato, T., Santos, R.S., Wirtz, P., 2000. Molecular insights into the taxonomic status of Coris atlantica (Pisces:Labridae). J. Mar. Biol. Ass. UK 80, 929-933.

Kimura, M., 1980. A simple method for estimating evolutionary rate of base substitution through comparative studies of nucleotide sequences. J. Mol. Evol. 16, 111-120.

Kuhner, M.K., Yamato, J., Felsenstein, J., 1998. Maximum likelihood estimation of population growth rates based on the coalescent. Genetics 149, 429-434.

Lee, W.J., Conroy, J., Howell, W.H., Kocher, T.D., 1995. Structure and evolution of teleost mitochondrial control regions. J. Mol. Evol. 41, 54-66.

Lemaire, C., Versini, J-J., Bonhomme, F., 2005. Maintenance of genetic differentiation across a transition zone in the sea: discordance between nuclear and cytoplasmic markers. J. Evol. Biol. 18, 70-80.

Lloris, D., Rucabado, J., Figueroa, H., 1991. Biogeography of the Macaronesian ichthyofauna (the Azores, Madeira, the Canary islands, Cape Verde and the African enclave) Boletim do Museu Municipal do Funchal. 43(234), 191-241.

Mapstone, G.M., Wood, E.M., 1975. The ethology of Abudefduf luridus and Chromis chromis (Pisces, Pomacentridae) form the Azores. J. Zool. (Lond). 175, 179-199.

Miller, P.J., 1984. The gobiid fishes of temperate Macaronesia (eastern Atlantic). J. Zool. Lond. 204, 363-412.

Naciri, M., Lemaire, C., Borsa, P., Bonhomme, F., 1999. Genetic study of the Atlantic/Mediterranean transition in Sea bass (Dicentrarchus labrax). J. Hered. 90, 591-596.

Prud'homme van Reine, W.F., 1988. Phytogeography of seaweeds of the Azores. Helgoländer Meeresunters. 42, 165-185.

Raventós, N., Macpherson, E., 2001. Planktonic larval duration and settlement marks on the otoliths of Mediterranean littoral fishes. Mar. Biol. 138, 1115-1120.

Rogers, A.R., 1995. Genetic evidence for a Pleistocene population explosion. Evolution 49, 608-615.

Rogers, A.R., Harpending, H., 1992. Population growth makes waves in the distribution pf pairwise genetic differences. Mol. Biol. Evol. 93, 552-569.

Rozas, J., Sánchez-Del Barrio, J.C., Messeguer, X., Rozas, R., 2003. DnaSP, DNA polymorphism analyses by the coalescent and other methods. Bioinformatics 19, 2496-2497.

Sambrook, J., Fritsch, E.F., Maniatis, T., 1989. Molecular Cloning a Laboratory Manual, second ed. Cold Spring Harbor Laboratory Press, New York.

Santos, R.S., Hawkins, S., Monteiro, L.R., Alves, M., Isidro, E.J., 1995. Marine research, resources and conservation in the Azores. Aquat Conserv: Mar. Freshwater Ecosystems 5, 311-354.

Schneider, S., Excoffier, L., 1999. Estimation of past demographic parameters from the distribution of pairwise differences when the mutation rates vary among sites: application to human mitochondrial DNA. Genetics 152, 1079-1089. 
Schneider, S., Roessli, D., Excoffier, L., 2000 ARLEQUIN, Version 2.000: A Software for Population Genetics Data Analysis. University of Geneva, Switzerland.

Stamatis, C., Trianfylidis, A., Moutou, K.A., Mamuris, Z., 2004. Mitochondrial DNA variation in Northeast Atlantic and Mediterranean populations of Norway lobster, Nephrops norvegicus. Mol. Ecol. 13, 1377 1390.

Stramma, L., 1984. Geostrophic transport in the warm water sphere of the eastern subtropical North Atlantic. J. Mar. Res. 42, 537-558.

Swofford, D.L., 1998. PAUP: Phylogenetic Analysis Using Parsimony and Other Methods. Sinauer Associates, Sunderland, MA.

Tajima, F., 1989. The effect of change in population size on DNA polymorphism. Genetics 123, 597-660.

Templeton, A.R., Crandall, K.A., Sing, C.F., 1992. A cladistic analysis of phenotipic associations with haplotypes inferred from restriction endonuclease mapping. III. Cladogram estimation. Genetics 132, 619-633.

Thiede, J., 1978. A glacial Mediterranean. Nature 276, 680-683.
Wares, J.P., Cunningham, C.W., 2001. Phylogeography and historical ecology of the north Atlantic intertidal. Evolution 55, 2455-2469.

Weerdt, H.W., 1989. Phylogeny and vicariance biogeography of North Atlantic Chalinidae (Haplosclerida, Demonspongiae). Beaufortia. 39 (3), 55-88.

Wirtz, P., Martins, H.R., 1993. Notes on some rare and little known marine invertebrates from the Azores, with a discusion on the zoogeography of the region. Arquipélago-Life and Earth Sciences A 11, 55-63.

Wood, E.M., 1977. A review of damselfishes (Pisces: Pomacentridae) of the genus Chromis from the central and eastern Atlantic and the Mediterranean. J. Fish. Biol. 10, 331-345.

Zander, C.D., 1980. Zoogeography and speciation of Mediterranean blennioids. Journées de Etudes Systématiques et Biogéographiques de Mediterraneen, CIESM, Cagliari, pp. 13-38.

Zardoya, R., Castilho, R., Grande, C., Favre-Krey, L., Caetano, S., Marcato, S., Krey, G., Patarnello, T., 2004. Differential population structuring of two closely related fish species, the mackerel (Scomber scombrus) and the chub mackerel (Scomber japonicus), in the Mediterranean Sea. Mol. Ecol. 13, 1785-1798. 